\title{
A Chemoenzymatic Synthesis of the Sex Pheromone of Lasioderma
}

\section{serricorne $\mathbf{F}$.}

\author{
Ronaldo A. Pilli*, and Valéria B. Riatto \\ Instituto de Química, UNICAMP, C.P. 6154, 13083-970 Campinas - SP, Brazil; \\ e-mail: pilli@iqm.unicamp.br andvbriatto@iqm.unicamp.br
}

Received: July 15, 1998

\begin{abstract}
A síntese quimioenzimática da forma enantiomericamente enriquecida (80\% ee) da (-)-serricornina (1), feromônio sexual da praga do fumo Lasioderma serricorne F., foi alcançada em 8 etapas e $13 \%$ de rendimento total a partir de (R)-3-hidroxipentanoato de metila, obtido da redução de 3-oxopentanoato de metila com fermento de padaria ( $S$. cerevisiae $)$ na presença de álcool alílico como inibidor enzimático.
\end{abstract}

A short and efficient preparation of enantiomerically enriched (80\% ee) (-)-serricornine (1), the sex pheromone of the cigarette beetle Lasioderma serricorne F., was developed in 8 steps and $13 \%$ overall yield from methyl (R)-3-hydroxypentanoate readily prepared by baker's yeast reduction of methyl 3-oxopentanoate in the presence of allyl alcohol as enzyme inhibitor.

Keywords: (-)-serricornine, pheromone, synthesis, S. cerevisiae

\section{Introduction}

The two-electron reduction of carbonyls by NAD(P)H is a highly valued process for the preparation of chiral building blocks in the total synthesis of enantiomerically pure natural products due to its ability to differentiate the enantiotopic faces of carbonylic substrates ${ }^{1,2}$.

However, the nicotinamide cofactors are rather expensive to be used in stoichiometric amounts and the preparative use of nicotinamide cofactor dependant oxidoredutases usually requires the recycling of the cofator or the use of whole cell preparations. The later may show a different reactivity profile from the purified enzyme due to the action of other oxidoreductases, and may be even superior for many applications.

In both cases, the stereoselectivity and yield may be generally high but access to both enantiomeric series of a chiral alcohol from the same prochiral substrate is generally not possible. Much effort has been directed towards screening different microorganisms, modifying the substrate and the reaction conditions in order to improve the scope of biocatalyzed carbonyl reductions $\mathrm{s}^{3,4,5}$.

The reduction of methyl 3-oxopentanoate with baker's yeast (Saccharomyces cerevisiae) can be directed to afford either methyl (R)-3-hydroxypentanoate ( $86 \%$ ee) when baker's yeast immobilized in polyurethane is employed ${ }^{6}$ or its antipode ( $89 \%$ ee) when the reduction is carried out with added $\mathrm{MgCl}_{2}$ and baker's yeast immobilized in magnesium alginate ${ }^{7}$.

The scenario is worse for the baker's yeast reduction of 2-methyl-3-oxopentanoates where up to four stereoisomers can conceivably be formed. So far a preparatively useful procedure employing baker's yeast has not been developed for such substrates, although the preparation of $(2 \mathrm{~S}, 3 \mathrm{~S})$ isomer has been achieved from the reduction of ethyl 2-methyl-3-oxopentanoate with some fungal strains ${ }^{8}$.

Nakamura and coworkers have devised a practical method for the baker's yeast reduction of 3-oxopentanoates either to the corresponding (R)- or (S)-3-hydroxypentanoates ${ }^{9,10}$ taking advantage of the selective inhibition of either the L- or D-enzymes present in S. cerevisiae ${ }^{11}$.

This protocol not only provides an enantiodivergent approach to these highly useful building blocks but also allows the preparation of (R,R)- and (S,S)-2-methyl-3-hydroxypentanoates in good diastereoisomeric and enantiomeric excesses when the reduction is followed by stereoselective Fràter alkylation ${ }^{12}$. In fact, Mori and Watanabe have used Fràter's alkylation of methyl (R)-2hydroxypentanoate, prepared by oxidation of pentanoic 
acid with Candida rugosa, to synthesize (-)-serricornine (1), the sex pheromone of the cigarette beetle Lasioderma serricorne $\mathrm{F}$., in 13 steps and $7.6 \%$ overall yield ${ }^{13}$.

\section{Experimental}

${ }^{1} \mathrm{H}-\mathrm{NMR}$ spectra were recorded in $\mathrm{CDCl}_{3}$ solution at $300 \mathrm{MHz}$ and ${ }^{13} \mathrm{C}$-NMR spectra in $\mathrm{CDCl}_{3}$ solution at 75.5 $\mathrm{MHz}$ (unless otherwise noted) with a Varian Gemini 2000 or a Bruker AC-300P instrument. Chemical shifts are expressed in ppm relative to tetramethylsilane followed by multiplicity (s, singlet; d, doublet; t, triplet; q, quartet; qt, quintet; $\mathrm{m}$, multiplet), coupling constant $(\mathrm{Hz})$ and number of protons. Infrared spectra were recorded on a Perkin-Elmer 399B or 1600 series spectrophotometer. Mass spectra were obtained via electron impact $(30 \mathrm{eV})$ on a Varian MAT 311A spectrometer. Optical rotations were measured at $25{ }^{\circ} \mathrm{C}$ in a Polamat A (Carl Zeiss) at $546 \mathrm{~nm}$ (mercury line) and corrected to $589 \mathrm{~nm}$ (sodium D line).

GC analyses were performed in a Hewlett-Packard 5890 series II chromatograph equipped with flame ionization detector, nitrogen as the carrier gas and capillary columns (30 m x $0.53 \mathrm{~mm}$ ) with $1 \%$ phenylmethylsilicone (HP-1) or cross-linked polyethyleneglycol (Carbowax $20 \mathrm{M})$ as stationary phases. Chiral GC analyses were performed with capillary columns $(0.25 \mathrm{~mm}$ i.d, $25 \mathrm{~m}$ length $)$ packed with heptakis-(2,6-methyl-3-pentyl)- $\beta$-cyclodextrine/OV-17 as stationary phase. GC-MS analyses were performed on a Hewlett-Packard 5890 series II gas chromatograph coupled to a MSD 5970 mass detector equipped with a capillary column (Carbowax 20M, $25 \mathrm{~m}$ x $0.20 \mathrm{~mm}$ x $0.33 \beta$ ).

Column chromatography was performed using silicagel (70-230 Mesh), except when stated otherwise, and reactions were monitored by TLC (plates from MachereyNagel, Germany).

Baker's yeast employed was purchased from Sigma -Aldrich (YSC-2, type 2) and Fleischmann, Brazil.

Tetrahydrofuran was treated with sodium/benzophenone and distilled immediately prior to use. Dichloromethane, triethylamine, diisopropylamine and benzene were treated with calcium hydride and distilled immediately prior to use. Acetic and propionic anhydride, and allyl alcohol were distilled prior to use. Potassium tert-butoxide was sublimed immediately prior to use. The remaining reagents employed were purchased from commercial suppliers and used without further purification. The reactions involving anhydrous solvents were carried out under argon atmosphere.

\section{(-)-Methyl (R)-3-hydroxypentanoate (2)}

To a suspension of dry baker's yeast $(7.7 \mathrm{~g})$ in water (77 $\mathrm{mL})$ at $30^{\circ} \mathrm{C}$ was added allyl alcohol $(0.13 \mathrm{~mL}, 1.9 \mathrm{mmol})$ and the whole mixture was stirred for $1 \mathrm{~h}$ at $30^{\circ} \mathrm{C}$. Methyl 3-oxopentanoate $(0.50 \mathrm{~g}, 3.8 \mathrm{mmol})$ and glucose $(7.7 \mathrm{~g})$ were added and the mixture was stirred 1 day at $30^{\circ} \mathrm{C}$. Celite was then added to the suspension and filtered. The filtrate was extracted with $\mathrm{Et}_{2} \mathrm{O}(3 \times 15 \mathrm{~mL})$, the organic phase was washed with water $(10 \mathrm{~mL})$, brine $(10 \mathrm{~mL})$ and dried over $\mathrm{MgSO}_{4}$ After filtration, the solvent was evaporated under reduced pressure and the residue was purified by Kugelrohr distillation $\left(70-80{ }^{\circ} \mathrm{C}, 1 \mathrm{~mm} \mathrm{Hg}\right)$ to afford $0.45 \mathrm{~g}(3.4 \mathrm{mmol})$ of (-)-2 (88\% yield, $80 \% \mathrm{ee})$ as a colorless oil. ${ }^{1} \mathrm{H}-\mathrm{NMR}\left(\mathrm{CCl}_{4}\right): \delta 0.96(\mathrm{t}, 3 \mathrm{H}, \mathrm{J}=7)$; 1.43 1.49 (m, 2H); 2.33 (dd, $1 \mathrm{H}, \mathrm{J}=16$ and 8$) ; 2.41(\mathrm{dd}, 1 \mathrm{H}, \mathrm{J}$ $=16$ and 4$) ; 3.08($ br s, $1 \mathrm{H}) ; 3.67(\mathrm{~s}, 3 \mathrm{H}) ; 3.81-3.84(\mathrm{~m}$, $1 \mathrm{H}) .{ }^{13} \mathrm{C}-\mathrm{NMR}\left(\mathrm{CCl}_{4}\right): \delta 9.8 ; 29.3 ; 40.7 ; 51.0 ; 68.6 ; 172.4$. IR (film): $3431 ; 1736 \mathrm{~cm}^{-1} .[\alpha]_{\mathrm{D}}-32.5\left(1.31, \mathrm{CHCl}_{3}\right)$.

\section{(-)-Methyl (2R,3R)-3-hydroxy-2-methylpentanoate (3)}

A solution of LDA was prepared by the dropwise addition of n-BuLi 1.55 $\mathrm{M}$ in n-hexane (15 mL, $23 \mathrm{mmol})$ to a stirred solution of ${ }^{\mathrm{i}} \mathrm{Pr}_{2} \mathrm{NH}(3.3 \mathrm{~mL}, 23 \mathrm{mmol})$ in THF (8 $\mathrm{mL})$ at $0{ }^{\circ} \mathrm{C}$ under argon. The mixture was stirred $30 \mathrm{~min}$ at $0{ }^{\circ} \mathrm{C}$ and then cooled to $-78^{\circ} \mathrm{C}$. A solution of (-)-2 (1.53 $\mathrm{g}, 11.6 \mathrm{mmol})$ in THF $(5 \mathrm{~mL})$ was added dropwise and the mixture was stirred $45 \mathrm{~min}$ at $0{ }^{\circ} \mathrm{C}$. A solution of $\mathrm{MeI}(1.10$ $\mathrm{mL}, 17.4 \mathrm{mmol})$ in DMPU $(4.7 \mathrm{~mL})$ was added dropwise to the solution at $-40{ }^{\circ} \mathrm{C}$ and the reaction was stirred for 45 $\min$. The reaction temperature was allowed to reach room temperature and it was quenched with satd. aq. $\mathrm{NH}_{4} \mathrm{Cl}$ $(7 \mathrm{~mL})$ at $0{ }^{\circ} \mathrm{C}$ and extracted with $\mathrm{Et}_{2} \mathrm{O}(3 \times 10 \mathrm{~mL})$. The organic phase was washed with brine $(10 \mathrm{~mL})$, dried over $\mathrm{MgSO}_{4}$, filtered and concentrated to afford $1.19 \mathrm{~g}$ of diastereoisomeric mixture of $(-)-3$ (anti:syn ratio $=8: 1$ ) which was used in the next step without further purification. ${ }^{1} \mathrm{H}-\mathrm{NMR}: \delta 0.98(\mathrm{t}, 3 \mathrm{H}, \mathrm{J}=7) ; 1.20(\mathrm{~d}, 3 \mathrm{H}, \mathrm{J}=7) ; 1.36-1.66$ $(\mathrm{m}, 2 \mathrm{H}) ; 2.56(\mathrm{qt}, 1 \mathrm{H}, \mathrm{J}=7) ; 2.72(\mathrm{br} \mathrm{s}, 1 \mathrm{H}) ; 3.58-3.67(\mathrm{~m}$, $1 \mathrm{H}) ; 3.71$ (s, 3H). ${ }^{13} \mathrm{C}-\mathrm{NMR}: \delta 9.7 ; 14.2 ; 27.4 ; 44.8 ; 51.7$; 74.5; 176.4. IR (film): $3426 ; 1735 \mathrm{~cm}^{-1}$.

\section{(+)-(2S,3R)-3-Hydroxy-2-methylpentanediol (4a)}

To a suspension of $\mathrm{LiAlH}_{4}(0.620 \mathrm{~g}, 16.3 \mathrm{mmol})$ in THF $(20 \mathrm{~mL})$ at $0{ }^{\circ} \mathrm{C}$ was added a solution of (-)-3 (1.19 g, 8.14 $\mathrm{mmol})$ in THF $(8 \mathrm{~mL})$. The reaction mixture was allowed to stir overnight at room temperature, diluted with $\mathrm{Et}_{2} \mathrm{O}(20$ $\mathrm{mL})$ and successively treated at $0{ }^{\circ} \mathrm{C}$ with water $(0.63 \mathrm{~mL})$, $10 \%$ aqueous $\mathrm{NaOH}(0.63 \mathrm{~mL})$ and water $(1.88 \mathrm{~mL})$. The inorganic solids were filtered and washed with $\mathrm{Et}_{2} \mathrm{O}$ (40 $\mathrm{mL})$. The organic extracts were dried over $\mathrm{MgSO}_{4}$ and concentrated to afford (+)-4a $(0.86 \mathrm{~g}, 7.3 \mathrm{mmol})$ which was used in the next step without further purification. ${ }^{1} \mathrm{H}-\mathrm{NMR}$ : $\delta 0.87(\mathrm{~d}, 3 \mathrm{H}, \mathrm{J}=7) ; 0.97(\mathrm{t}, 3 \mathrm{H}, \mathrm{J}=7) ; 1.37-1.78(\mathrm{~m}, 3 \mathrm{H})$; 3.36 (br s, 2H); 3.49 (dt, 1H, J = 7 and 3); 3.61 (dd, 1H, J $=11$ and 7$) ; 3.76(\mathrm{dd}, 1 \mathrm{H}, \mathrm{J}=11$ and 4$) .{ }^{13} \mathrm{C}-\mathrm{NMR}: \delta 9.3$; $13.7 ; 27.7 ; 39.2 ; 67.4 ; 78.2$. IR (film): $3346,1459 \mathrm{~cm}^{-1}$. $[\alpha]_{\mathrm{D}}$ $+3.9\left(1.08, \mathrm{CHCl}_{3}\right)$. 
(-)-(2S,3R)-2-Methyl-1-O-p-toluenesulfonyl-1,3-pentanediol (4b)

To a solution of diol (+)-4a $(0.86 \mathrm{~g}, 7.2 \mathrm{mmol})$ in $\mathrm{CH}_{2} \mathrm{Cl}_{2}(15 \mathrm{~mL})$ at $0{ }^{\circ} \mathrm{C}$ was added p-toluenesulfonyl chloride (1.52 g, $7.96 \mathrm{mmol})$, triethylamine $(1.1 \mathrm{~mL}, 7.9$ mmol) and catalytic amount ( $c a .10 \mathrm{~mol} \%)$ of N,N-dimethyl-4-aminopyridine (4-DMAP). The mixture was allowed to stand at $-15{ }^{\circ} \mathrm{C}$ overnight and it was then diluted with $\mathrm{CH}_{2} \mathrm{Cl}_{2}(20 \mathrm{~mL})$. The organic phase was washed with water $(10 \mathrm{~mL}), 10 \% \mathrm{HCl}(10 \mathrm{~mL})$, satd. aq. $\mathrm{NaHCO}_{3}(10$ $\mathrm{mL})$, brine $(10 \mathrm{~mL})$ and dried over $\mathrm{MgSO}_{4}$. After filtration and evaporation the residue was chromatographed on silica gel (10\% AcOEt in hexanes, v/v) to afford (-)-4b (1.77 g, $6.50 \mathrm{mmol}$ ) in $56 \%$ overall yield (3 steps from (-)-2), as a colorless oil. ${ }^{1} \mathrm{H}-\mathrm{NMR}$ : $\delta 0.93(\mathrm{t}, 3 \mathrm{H}, \mathrm{J}=7) ; 0.93(\mathrm{~d}, 3 \mathrm{H}, \mathrm{J}$ $=7) ; 1.32-1.41(\mathrm{~m}, 1 \mathrm{H}) ; 1.48-1.59(\mathrm{~m}, 1 \mathrm{H}) ; 1.80-1.86(\mathrm{~m}$, $2 \mathrm{H}) ; 2.44(\mathrm{~s}, 3 \mathrm{H}) ; 3.40(\mathrm{dt}, 1 \mathrm{H}, \mathrm{J}=8$ and 3$) ; 4.06(\mathrm{dd}, 1 \mathrm{H}$, $\mathrm{J}=10$ and 4); $4.12(\mathrm{dd}, 1 \mathrm{H}, \mathrm{J}=10$ and 6$) ; 7.35(\mathrm{~d}, 2 \mathrm{H}, \mathrm{J}=$ 8); $7.78(\mathrm{~d}, 2 \mathrm{H}, \mathrm{J}=8) .{ }^{13} \mathrm{C}-\mathrm{NMR}: \delta$ 9.6; 13.6; 21.6; 27.0; $38.4 ; 72.7 ; 73.7 ; 127.8 ; 129.8 ; 132.9 ; 144.7$. IR (film): $3548,1598,1356,1176 \mathrm{~cm}^{-1} .[\alpha]_{\mathrm{D}}-2.8\left(3.0, \mathrm{CH}_{2} \mathrm{Cl}_{2}\right)$.

(+)-(2S,3S)-3-O-p-Nitrobenzoyl-2-methyl-1-O-p-toluenesulfonyl-1,3-pentanediol (5)

To a solution of (-)-4b (0.27 g, $1.0 \mathrm{mmol}), \mathrm{PPh}_{3}(0.91$ $\mathrm{g}, 3.5 \mathrm{mmol})$ and p-nitrobenzoic acid $(0.58 \mathrm{~g}, 3.5 \mathrm{mmol})$ in benzene $(6 \mathrm{~mL})$ at $0{ }^{\circ} \mathrm{C}$ was added a solution of diethyl azodicarboxylate (DEAD) $(0.55 \mathrm{~mL}, 3.5 \mathrm{mmol})$ in benzene $(3 \mathrm{~mL})$. The ice-bath was removed and the mixture was stirred overnight at room temperature. The solvent was removed and the residue was purified by silica gel chromatography (10\% AcOEt in hexanes, v/v) to afford $(+)-5(0.33$ $\mathrm{g}, 0.79 \mathrm{mmol}$ ) as a yellow solid (m.p. $=64-65^{\circ} \mathrm{C}$ ), in $79 \%$ yield. ${ }^{1} \mathrm{H}-\mathrm{NMR}$ : $\delta 0.92(\mathrm{t}, 3 \mathrm{H}, \mathrm{J}=7) ; 1.04(\mathrm{~d}, 3 \mathrm{H}, \mathrm{J}=7)$; $1.63-1.79(\mathrm{~m}, 2 \mathrm{H}) ; 2.24-2.27(\mathrm{~m}, 1 \mathrm{H}) ; 2.38(\mathrm{~s}, 3 \mathrm{H}) ; 3.97$ (d, $2 \mathrm{H}, \mathrm{J}=6) ; 5.11-5.17(\mathrm{~m}, 1 \mathrm{H}) ; 7.27(\mathrm{~d}, 2 \mathrm{H}, \mathrm{J}=8) ; 7.74(\mathrm{~d}$, $2 \mathrm{H}, \mathrm{J}=8) ; 8.12(\mathrm{~d}, 2 \mathrm{H}, \mathrm{J}=9) ; 8.27(\mathrm{~d}, 2 \mathrm{H}, \mathrm{J}=9)$. ${ }^{13} \mathrm{C}-\mathrm{NMR}$ : $\delta 10.0 ; 11.1 ; 21.6 ; 24.2 ; 35.8 ; 71.3 ; 76.6 ; 123.5 ; 127.9$; $129.8 ; 130.6 ; 132.6 ; 135.5 ; 144.8 ; 150.5 ; 164.0$. IR (KBr): $1714 ; 1598 ; 1526 ; 1357 ; 1177 \mathrm{~cm}^{-1} .[\alpha]_{\mathrm{D}}+8.5(2.0$, $\mathrm{CH}_{2} \mathrm{Cl}_{2}$ ).

\section{(-)-(2S,3S)-2-Methyl-1-O-p-toluenesulfonyl-1,3-pen-} tanediol (6a)

To a solution of (+)-5 ( $0.80 \mathrm{~g}, 1.9 \mathrm{mmol})$ in $\mathrm{MeOH}(20$ $\mathrm{mL})$ at room temperature was added water $(5 \mathrm{~mL})$ and $\mathrm{K}_{2} \mathrm{CO}_{3}(1.57 \mathrm{~g}, 11.4 \mathrm{mmol})$. The mixture was stirred $2 \mathrm{~h}$ at room temperature, then diluted with $\mathrm{Et}_{2} \mathrm{O}(30 \mathrm{~mL})$. The phases were separated and the aqueous phase was extracted with $\mathrm{Et}_{2} \mathrm{O}(3 \times 5 \mathrm{~mL})$. The combined organic phases were washed with brine $(10 \mathrm{~mL})$, dried over $\mathrm{MgSO}_{4}$ and concentrated under reduced pressure. Purification by silica gel chromatography (10\% AcOEt in hexanes, v/v) afforded
(-)-6 (0.48 g, $1.8 \mathrm{mmol})$ in 93\% yield, as a colorless oil. ${ }^{1} \mathrm{H}-\mathrm{NMR}: \delta 0.85$ (d, 3H, J = 7); $0.92(\mathrm{t}, 3 \mathrm{H}, \mathrm{J}=7) ; 1.35-1.55$ (m, 2H); 1.85-1.95 (m, 2H); 2.45 (s, 3H); 3.62 (ddd, 1H, J $=8,5$ and 3); $3.89(\mathrm{dd}, 1 \mathrm{H}, \mathrm{J}=10$ and 6$) ; 4.08(\mathrm{dd}, 1 \mathrm{H}, \mathrm{J}$ $=10$ and 8); $7.35(\mathrm{~d}, 2 \mathrm{H}, \mathrm{J}=8) ; 7.78(\mathrm{~d}, 2 \mathrm{H}, \mathrm{J}=8)$. ${ }^{13}$ C-NMR: $\delta 9.3 ; 10.4 ; 21.6 ; 27.2 ; 37.3 ; 72.0 ; 72.8 ; 127.8$; 129.8; 132.9; 144.8. IR (film): 3548, 1598, 1356, 1176 $\mathrm{cm}^{-1} \cdot[\alpha]_{\mathrm{D}}-2.1\left(3.0, \mathrm{CH}_{2} \mathrm{Cl}_{2}\right)$.

\section{(-)-(2S,3S)-3-O-Propionyl-2-methyl-1-O-p-toluenesul- fonyl-1,3-pentanediol (6b)}

To a solution of (-)-6a $(0.27 \mathrm{~g}, 1.0 \mathrm{mmol})$ in $\mathrm{CH}_{2} \mathrm{Cl}_{2}(3$ $\mathrm{mL})$ at room temperature was added triethylamine $(0.18$ $\mathrm{mL}, 1.3 \mathrm{mmol})$, propionic anhydride $(0.15 \mathrm{~mL}, 1.2 \mathrm{mmol})$ and a catalytic amount ( $c a .10 \mathrm{~mol} \%$ ) of N,N-dimethyl-4aminopyridine (4-DMAP). The mixture was stirred $1.5 \mathrm{~h}$ at room temperature and poured into water. The layers were separated and the organic phase was washed with $10 \% \mathrm{HCl}$ $(1 \mathrm{~mL})$, satd. aq. $\mathrm{NaHCO}_{3}(1 \mathrm{~mL})$, brine $(1 \mathrm{~mL})$, dried over $\mathrm{MgSO}_{4}$ and concentrated under reduced pressure. The residue was purified by silica gel chromatography $(10 \% \mathrm{AcOEt}$ in hexanes, v/v) to afford (-)-6b $(0.27 \mathrm{~g}, 0.82 \mathrm{mmol})$ in $82 \%$ yield, as a colorless oil. ${ }^{1} \mathrm{H}-\mathrm{NM}$ : $\delta 0.83(\mathrm{t}, 3 \mathrm{H}, \mathrm{J}=7) ; 0.92$ $(\mathrm{d}, 3 \mathrm{H}, \mathrm{J}=7) ; 1.09$ (t, 3H, J = 7); 1.46-1.62 (m, 2H); 2.05-2.09 (m, 1H); 2.25 (dq, $2 \mathrm{H}, \mathrm{J}=7$ and 2); $2.45(\mathrm{~s}, 3 \mathrm{H})$; $3.92(\mathrm{dd}, 1 \mathrm{H}, \mathrm{J}=10$ and 6$) ; 3.86(\mathrm{dd}, 1 \mathrm{H}, \mathrm{J}=10$ and 7$)$; 4.79-4.85 (m, 1H); $7.35(\mathrm{~d}, 2 \mathrm{H}, \mathrm{J}=8) ; 7.79(\mathrm{~d}, 2 \mathrm{H}, \mathrm{J}=8)$. ${ }^{13} \mathrm{C}-\mathrm{NMR}\left(\mathrm{CDCl}_{3}, 75.5\right): \delta 9.2 ; 9.9 ; 11.0 ; 21.6 ; 24.2 ; 27.6$; $35.8 ; 71.8 ; 74.4 ; 128.4 ; 129.8 ; 132.8 ; 144.8 ; 173.9$. IR (film): $1735 ; 1598,1362,1177 \mathrm{~cm}^{-1} .[\alpha]_{\mathrm{D}}-1.06(2.7$, $\mathrm{CH}_{2} \mathrm{Cl}_{2}$ ).

(-)-(3S, 5S,6S)-6-Ethyl-tetrahydro-3,5-dimethyl-2H-pyran2-one (7)

To a suspension of freshly sublimed tert-BuOK $(0.41$ $\mathrm{g}, 3.6 \mathrm{mmol})$ in THF $(5 \mathrm{~mL})$ at $0{ }^{\circ} \mathrm{C}$ was added dropwise a solution of (-)-6b (0.30 g, $0.91 \mathrm{mmol})$ in THF (5 mL). The cooling bath was removed and the reaction was stirred for $30 \mathrm{~min}$ at room temperature. The solvent was removed under reduced pressure, the residue was taken up in $\mathrm{Et}_{2} \mathrm{O}$ $(30 \mathrm{~mL})$, acidified with conc. $\mathrm{HCl}(0.76 \mathrm{~mL})$ and stirred overnight at room temperature. The layers were separated and the aqueous phase was extracted with $\mathrm{Et}_{2} \mathrm{O}(3 \times 1 \mathrm{~mL})$. The combined organic layers were dried over $\mathrm{MgSO}_{4}$ and concentrated under reduced pressure. Silica gel cromatography (8\% AcOEt in hexanes, $\mathrm{v} / \mathrm{v})$ of the crude product afforded (-)-7 (0.078 g, $0.50 \mathrm{mmol})$ as an 8:1 mixture with its $\mathrm{C}(4)$ epimer (serricornine numbering), in 55\% yield, as a colorless oil. ${ }^{1} \mathrm{H}-\mathrm{NMR}$ : $\delta 0.99(\mathrm{t}, 3 \mathrm{H}, \mathrm{J}=7) ; 0.99(\mathrm{~d}, 3 \mathrm{H}$, $\mathrm{J}=7) ; 1.30(\mathrm{~d}, 3 \mathrm{H}, \mathrm{J}=7) ; 1.48-1.62(\mathrm{~m}, 1 \mathrm{H}) ; 1.63-1.79(\mathrm{~m}$, $2 \mathrm{H}) ; 1.86-1.98(\mathrm{~m}, 1 \mathrm{H}) ; 2.03-2.10(\mathrm{~m}, 1 \mathrm{H}) ; 2.58-2.67(\mathrm{~m}$, $1 \mathrm{H}) ; 4.24$ (ddd, $1 \mathrm{H}, \mathrm{J}=8 ; 6$ and 3 ). ${ }^{13} \mathrm{C}-\mathrm{NMR}: \delta 9.9 ; 11.3$; 17.9; 25.6; 29.4; 31.3; 36.0; 85.4; 174.6. IR (film): 1732 
$\mathrm{cm}^{-1} . \mathrm{MS}(\mathrm{m} / \mathrm{z}): 156\left(\mathrm{M}^{+}, 0.6 \%\right), 127(11 \%), 98(18 \%), 70$ (44\%), $56(100 \%)$.

\section{(-)-(4S,6S, 7S)-7-Hydroxy-4,6-dimethyl-3-nonanone (1)}

To a solution of (-)-7 $(0.11 \mathrm{~g}, 0.71 \mathrm{mmol})$ in $\mathrm{Et}_{2} \mathrm{O}(10$ $\mathrm{mL})$ at $-78{ }^{\circ} \mathrm{C}$ was added a $1.0 \mathrm{M}$ solution of ethylmagnesium bromide $(0.86 \mathrm{~mL}, 0.86 \mathrm{mmol})$ in $\mathrm{Et}_{2} \mathrm{O}$. After briefly warming to $0{ }^{\circ} \mathrm{C}$, the mixture was cooled again to $-78{ }^{\circ} \mathrm{C}$ before addition of $1.5 \mathrm{~mL}$ of a saturated $\mathrm{NH}_{4} \mathrm{Cl}$ solution. The layers were separated and the aqueous layer was extracted with $\mathrm{Et}_{2} \mathrm{O}(3 \times 2 \mathrm{~mL})$. The combined organic layers were dried over $\mathrm{MgSO}_{4}$ and concentrated. Silica gel cromatography (4\% AcOEt in hexanes, v/v) of the crude product afforded $0.092 \mathrm{~g}(0.50 \mathrm{mmol})$ of a mixture of the acyclic and hemiketal forms of the pheromone $\mathbf{1}$ in $70 \%$ yield, as a colorless oil. ${ }^{1} \mathrm{H}-\mathrm{NMR}$ : $\delta$ 0.79-1.08 $(\mathrm{m}, 24 \mathrm{H})$; $1.22-1.89(\mathrm{~m}, 15 \mathrm{H}) ; 2.45-2.51(\mathrm{~m}, 2 \mathrm{H}) ; 2.62-2.66(\mathrm{~m}, 1 \mathrm{H})$; 3.35-3.43 (m, 1H); 3.76-3.81 (m, 1H). ${ }^{13} \mathrm{C}-\mathrm{NMR}: \delta 7.1 ; 7.9$; $10.4 ; 10.6 ; 11.4 ; 13.4 ; 16.3 ; 16.5 ; 25.7 ; 27.2 ; 30.0 ; 30.6$; $32.6 ; 34.0 ; 35.3 ; 35.8 ; 36.4 ; 43.7 ; 72.7 ; 76.7 ; 98.7 ; 215.6$. IR (film): 3463; 1707; 1460; $1379 \mathrm{~cm}^{-1} . \mathrm{MS}(\mathrm{m} / \mathrm{z}): 186$ $\left(\mathrm{M}^{+}, 1 \%\right), 169(13 \%), 86(35 \%), 70$ (100\%), 57 (55\%), 43 $(60 \%)$. $[\alpha]_{\mathrm{D}}-28.1\left(1.08, \mathrm{CHCl}_{3}\right) ;$ lit. $^{21}:[\alpha]_{\mathrm{D}}-30.6(1.08$, $\left.\mathrm{CHCl}_{3}\right)$.

(-)-(4S,6S, 7S)-O-Acetyl-7-hydroxy-4,6-dimethyl-3nonanone $\mathbf{( 8 )}$

To a solution of a mixture of (-)-1 and it's hemiketal form $(0.028 \mathrm{~g}, 0.15 \mathrm{mmol})$ in pyridine $(0.5 \mathrm{~mL})$ at room temperature was added acetic anhydride $(0.040 \mathrm{~mL}, 0.45$ mmol) and a catalytic amount ( $c a .10 \mathrm{~mol} \%$ ) of N,N-dimethyl-4-aminopyridine (4-DMAP). The mixture was stirred $14 \mathrm{~h}$ at room temperature and poured into water. The layers were separated and the organic phase was washed with $10 \% \mathrm{HCl}(1 \mathrm{~mL})$, satd. aq. $\mathrm{NaHCO}_{3}(1 \mathrm{~mL})$, brine $(1$ $\mathrm{mL}$ ), dried over $\mathrm{MgSO}_{4}$ and concentrated. Silica gel cromatography $(10 \%$ AcOEt in hexanes, v/v) of the crude product afforded (-)-8 $(0.024 \mathrm{~g}, 0.10 \mathrm{mmol})$ in $70 \%$ yield, as a colorless oil. ${ }^{1} \mathrm{H}-\mathrm{NMR}: \delta 0.84(\mathrm{t}, 3 \mathrm{H}, \mathrm{J}=7) ; 0.86(\mathrm{~d}$, $3 \mathrm{H}, \mathrm{J}=7) ; 1.04(\mathrm{t}, 3 \mathrm{H}, \mathrm{J}=7) ; 1.06(\mathrm{~d}, 3 \mathrm{H}, \mathrm{J}=7) ; 1.24-1.36$ (m, 2H); 1.42-1.70 (m, 3H); $2.06(\mathrm{~s}, 3 \mathrm{H}) ; 2.42-2.52(\mathrm{~m}$, $2 \mathrm{H}) ; 2.59-2.70(\mathrm{~m}, 1 \mathrm{H}) ; 4.75$ (ddd, $1 \mathrm{H}, \mathrm{J}=5 ; 4$ and 2 ). ${ }^{13}$ C-NMR: $\delta 7.8 ; 10.1 ; 14.4 ; 16.6 ; 21.1 ; 24.1 ; 33.6 ; 34.2$; 35.8; 43.4; 78.1; 171.0; 215.2. IR (film): 1733; 1714; 1459; $1372 ; 1242 ; 1018 \mathrm{~cm}^{-1} \mathrm{MS}(\mathrm{m} / \mathrm{z}): 168$ (5\%), 111 (14\%), 86 (25\%), 69 (32\%), 57 (60\%), $43(100 \%)$. [ $\alpha]_{\mathrm{D}}-18.9(0.58$, hexane); lit. ${ }^{13}:[\alpha]_{\mathrm{D}}-18.2(0.58$, hexane).

\section{Results and Discussion}

Baker's yeast is an inexpensive and versatile microorganism which does not require any special growth conditions to be used on a preparative scale. On the other hand, major limitations are generallly associated with non-repro- ducible results due to the different strains of $S$. cerevisiae available from industrial sources.

As the methodology which employs an enzymatic inhibitor to control the stereochemical course of the reduction seemed appropriate for the preparation of some insect pheromones ${ }^{9}$, we initially evaluated two commercially available baker's yeast brands (Fleischmann, Brazil and Sigma, USA) in the reduction of methyl 3-oxopentanoate aiming to reach a preparatively useful access to enantiomerically enriched methyl (R)-3-hydroxypentanoate.

While both strains tested were able to efficiently reduce ethyl acetoacetate to ethyl (S)-3-hydroxybutanoate (70$75 \%$ isolated yield, $90-92 \%$ ee) only the yeast suplied by Sigma, USA efficiently converted methyl 3-oxopentanoate to the corresponding hydroxyester, albeit in low enantiomeric excess (Table 1, entry 1). At this point it is rather difficult to rationalize the lack of reactivity towards methyl 3-oxopentanoate observed for the baker's yeast supplied by Fleischmann, Brazil but morfological differences were evident when samples of each brand were examined by atomic force microscopy as the sample from Sigma, USA displayed extensive cell wall preservation when compared to the one from Fleischmann, Brazil ${ }^{14}$.

Using allyl alcohol as an enzymatic inhibitor, methyl (R)-3-hydroxypentanoate (-)-2 was obtained in good enantiomeric excess (Table 1, entries 2-4). Although some improvement in the enantiomeric excess of methyl (R)-3hydroxypentanoate (-)-(2) was observed upon increasing the inhibitor concentration it was accompanied by a significant decrease in the conversion of methyl 3-oxopentanoate to $(-)-2$.

On a preparative scale, we were able to isolate gram quantities of (-)-2 in $88 \%$ yield and $76-80 \%$ ee, after purification by Kugelrohr distillation $\left(1 \mathrm{~mm} \mathrm{Hg}, 70-80^{\circ} \mathrm{C}\right)$ when baker's yeast was previously incubated at $30{ }^{\circ} \mathrm{C}$ for 30 min with 0.5 equivalents of allyl alcohol.

Having secured a convenient access to enantiomerically enriched (-)-2 we proceeded to convert it to (-)-7, a known precursor of (-)-serricornine (1), employing an intramolecular alkylation step, as previously described during our studies on pheromone syntheses (Scheme 1) ${ }^{15,16}$.

The stereogenic center at C-6 (serricornine numbering) was established after Fràter's alkylation ${ }^{12}$ of (-)-2 which provided an 8:1 mixture of methyl (R,R)-3-hydroxy-2methylpentanoate (-)-3 and its epimer at C-2. The configuration of the major isomer was confirmed to be $2 R, 3 R$ by analysis of its ${ }^{1} \mathrm{H}$-NMR spectrum which displayed a coupling constant $\left(\mathrm{JH}_{2}-\mathrm{H}_{3}=7.0 \mathrm{~Hz}\right)$ characteristic of its anti relative configuration and a deshielding effect at $\mathrm{C}-2$ and C-3 (27.4 and $74.5 \mathrm{ppm}$, respectively) in the ${ }^{13} \mathrm{C}-\mathrm{NMR}$ spectrum ${ }^{17}$ of the major isomer when compared to the same carbons in the minor component (26.7 and $73.2 \mathrm{ppm}$, respectively). 
Table 1. Yields and enantiomeric excesses in the reduction of methyl 3-oxopentanonate with baker's yeast in the presence of allyl alcohol ${ }^{\text {a }}$

\begin{tabular}{lccc}
\hline Entry & Equivalents of allyl alcohol & Conversion $(\%)^{\mathrm{b}}$ & Enantiomeric excess $^{\mathrm{c}}(-)-\mathbf{2}$ \\
\hline 1 & - & 97 & 45 \\
2 & 0.5 & 100 & 76 \\
3 & 1.0 & 62 & 79 \\
4 & 2.0 & 30 & 82 \\
\hline
\end{tabular}

${ }^{\mathrm{a}}$ Mean value for 3 experiments; ${ }^{\mathrm{b}}$ Conversion determined by capillary GC analysis after $24 \mathrm{~h}$ at $30{ }^{\circ} \mathrm{C} ;{ }^{\mathrm{c}}$ Enantiomeric excess determined by chiral GC analysis (see Experimental section).

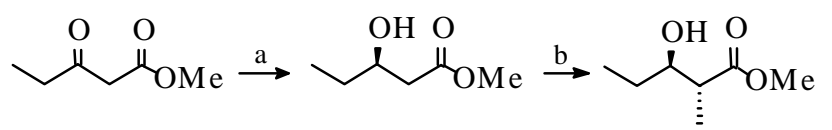

$(-)-2$

$(-)-3$

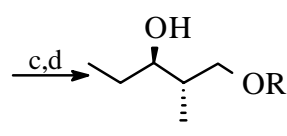

$(+)-\mathbf{4 a} \mathrm{R}=\mathrm{H}$

$(-)-4 b \mathrm{~b}=\mathrm{Ts}$

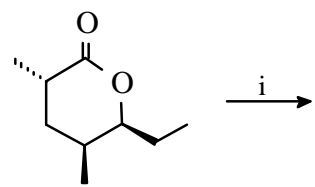

$(-)-7$

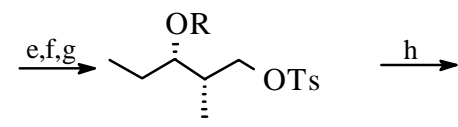

$(+)-5 \mathrm{R}=\mathrm{p}-\mathrm{NO}_{2} \mathrm{C}_{6} \mathrm{H}_{4}$

$(-)-6 a \mathrm{R}=\mathrm{H}$

$(-)-6 \mathbf{b} \mathrm{R}=\mathrm{COCH}_{2} \mathrm{CH}_{3}$

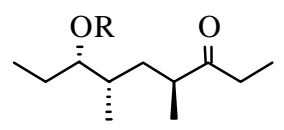

$\mathrm{j}\left(\begin{array}{l}(-)-\mathbf{1} R=\mathrm{H} \\ (-)-8 \mathrm{R}=\mathrm{Ac}\end{array}\right.$

Scheme 1. a) baker's yeast (YSC-1), $\mathrm{CH}_{2} \mathrm{CHCH}_{2} \mathrm{OH}$ ( $88 \%$ yield, $80 \%$ ee); b) i. LDA, THF, $-78^{\circ} \mathrm{C}$; ii. MeI, DMPU; c) LiAlH4, THF, rt; d) p-TsCl, Et3 $\mathrm{N}, \mathrm{CH}_{2} \mathrm{Cl}_{2}$, DMAP (cat.) (56\% yield, 3 steps); e) p- $\mathrm{NO}_{2} \mathrm{C}_{6} \mathrm{H}_{4} \mathrm{CO}_{2} \mathrm{H}$, $\mathrm{Ph}_{3} \mathrm{P}, \mathrm{DEAD}, \mathrm{C}_{6} \mathrm{H}_{6}$, rt (79\% yield); f) $\mathrm{K}_{2} \mathrm{CO}_{3}, \mathrm{MeOH}, \mathrm{H}_{2} \mathrm{O}$ (93\% yield); g) $\left(\mathrm{CH}_{3} \mathrm{CH}_{2} \mathrm{CO}\right)_{2} \mathrm{O}, \mathrm{Et}_{3} \mathrm{~N}, \mathrm{CH}_{2} \mathrm{Cl}_{2}$, DMAP(cat.) (82\% yield); h) tert$\mathrm{BuOK}$, THF, $0{ }^{\circ} \mathrm{C}$ (55\% yield); i) EtMgBr, Et $2 \mathrm{O},-78{ }^{\circ} \mathrm{C}$ (70\% yield); j) $\left(\mathrm{CH}_{3} \mathrm{CO}\right)_{2} \mathrm{O}, \mathrm{C}_{5} \mathrm{H}_{5} \mathrm{~N}$, DMAP(cat.) (70\% yield).

In order to reduce the number of purification steps, epimer separation was deferred until the preparation of (-)-4b which was obtained after lithium aluminum hydride reduction and selective monotosylation of the diol (+)-4a. After column chromatography on silica gel, alcohol (-)-4b was isolated in 56\% overall yield from (-)-2.

At this stage, we were ready to undertake the inversion of configuration at $\mathrm{C}-7$ (serricornine numbering) required to convert (-)-4b to (-)-serricornine (1). Mitsunobu inver$\operatorname{sion}^{18}$ afforded the corresponding p-nitrobenzoate $(+)-5$ in $79 \%$ yield which was straightforwardly converted to (-)-6a after basic hydrolysis (73\% overall yield).

The intramolecular alkylation, the key step in our approach to (-)-serricornine (1), was accomplished after Opropionylation of (-)-6a ( $82 \%$ yield) and treatment of a THF solution of the corresponding propionate (-)-6b with freshly sublimed potassium tert-butoxide at $0{ }^{\circ} \mathrm{C}$ followed

by acidification of the reaction mixture with conc. $\mathrm{HCl}$ and stirring at room temperature ${ }^{15,16}$. An 8:1 mixture of (-)-7 and its epimer at C-4 (serricornine numbering) was formed and the configuration of the major isomer was established as $4 \mathrm{~S}, 6 \mathrm{~S}, 7 \mathrm{~S}$ (serricornine numbering) by comparison of the ${ }^{1} \mathrm{H}-\mathrm{NMR}$ spectrum of the mixture with literature data for $(-)-7^{19}$.

Addition of ethylmagnesium bromide to (-)-7 at low temperature $\left(-78^{\circ} \mathrm{C}\right)$, followed by the addition of satd. aq. $\mathrm{NH}_{4} \mathrm{Cl}$, afforded after purification by column chromatography on silica gel (-)-serricornine (1) in $70 \%$ yield. The ${ }^{1} \mathrm{H}-$ and ${ }^{13} \mathrm{C}-\mathrm{NMR}$ data ${ }^{20}$ and optical rotation $\left([\alpha]_{\mathrm{D}}-28.1\right.$ $\left.\left(\mathrm{c} 1.08, \mathrm{CHCl}_{3}\right)\right)$ are in good agreement with those reported in the literature for (-)-1 (lit. ${ }^{21}:[\alpha]_{\mathrm{D}}-30.6$ (c1.08, hexane) but the presence of its hemiketal form makes an unambiguous assignment of the spectra difficult. In order to circumvent this problem, the acetyl derivative (-)-8 was prepared (70\% yield). Comparison of ${ }^{1} \mathrm{H}$ - and ${ }^{13} \mathrm{C}-\mathrm{NMR}$ spectra with literature data ${ }^{13,21}$ unambiguously established its identity and its enantiomeric excess was determined to be $80 \%\left([\alpha]_{\mathrm{D}}-18.9\right.$ (c 0.58 , hexanes); lit. ${ }^{13}:[\alpha]_{\mathrm{D}}-18.2$ (c 0.58 , hexanes)) after chiral GC analysis.

\section{Conclusion}

A short and efficient preparation (8 steps, $13 \%$ overall yield and $80 \%$ ee) of enantiomerically enriched (-)-serricornine (1) was developed from methyl (R)-3-hydroxypentanoate, efficiently prepared by baker's yeast reduction of methyl 3-oxopentanoate.

\section{Acknowledgements}

The authors gratefully acknowledge the financial support from FINEP (Brazil), CNPq (Brazil) and IFS (Sweden).

\section{References}

1. Mori, K. Tetrahedron 1989, 45, 3233.

2. Mori, K. Pure and Appl. Chem. 1994, 66, 1991.

3. Servi, S. Synthesis 1990, 1.

4. Csuk, K.; Glänzer, B.I. Chem. Rev. 1991, 91, 49.

5. Santaniello, E.; Ferraboschi, P.; Grisenti, P.; Manzocchi, A. Chem. Rev. 1992, 92, 1071. 
6. Nakamura, K.; Higaki, M.; Ushio, K.; Oka, S.; Ohno, A. Tetrahedron Lett. 1985, 26, 4213.

7. Nakamura, K.; Kawai, Y.; Oka, S.; Ohno, A. Tetrahedron Lett. 1989, 30, 2245.

8. Buisson, C.; Sanner, M.; Larcheveque, R.; Azerad, R. Tetrahedron Lett. 1987, 28, 3939.

9. Nakamura, K.; Inoue, K.; Ushio, K.; Oka, S.; Ohno, A. Chem. Lett. 1987, 679.

10. Nakamura, K.; Kawai, Y.; Ohno, A. Tetrahedron Lett. 1990, 31, 267.

11. Nakamura, K.; Kawai, Y.; Nakajima, N.; Ohno, A. J. Org. Chem. 1991, 56, 4778.

12. Fràter, G.; Müller, U.; Günther, W. Tetrahedron 1984 , 40, 1269.

13. Mori, K.; Watanabe, H. Tetrahedron 1985, 41, 3423.
14. Pereira, R.S.; Parizotto, N.A.; Baranauskas, V. Appl. Biochem. Biotech. 1996, 59, 135.

15. Pilli, R.A.; Murta, M.M. J. Org. Chem. 1993, 58, 338.

16. Pilli, R.A.; Andrade, C.K.Z. Synth. Commun. 1994, 24, 1994.

17. Heathcock, C.H.; Pirrung, M.C.; Sohn, J. J.Org. Chem. 1979, 44, 4294.

18. Mitsunobu, O. Synthesis 1981, 1.

19. Redlich, H.; Samm, K.; Lenfers, J.G.; Bruns, W. Carbohydrate Res. 1988, 174, 341.

20. Mori, M.; Chuman, T.; Kato, K. Tetrahedron Lett. 1984, 25, 2553.

21. Shimizu, I.; Hayashi, K.; Ide, N.; Oshima, M. Tetrahedron 1991, 47, 2991.

22. Mori, K.; Nomi, H.; Chuman, T.; Kohno, M.; Kato, K.; Noguchi, M. Tetrahedron 1982, 38, 3705.

FAPESP helped in meeting the publication costs of this article 